\title{
Antioxidant supplementation and serum lipids in patients with Graves' disease: Effect on LDL-cholesterol
}

\author{
VESNA BAČIĆ VRCA ${ }^{1 *}$ \\ LJILJANA MAYER ${ }^{2}$ \\ FRANJO ŠKREB ${ }^{3}$ \\ DARIO RAHELIC ${ }^{4}$ \\ SREĆKO MARUŠIĆ ${ }^{5}$ \\ 1 Department of Clinical Pharmacy \\ Faculty of Pharmacy and Biochemistry \\ University of Zagreb, Croatia \\ 2 Department of Medical Biochemistry \\ University Hospital »Sestre milosrdnice» \\ Zagreb, Croatia \\ ${ }^{3}$ Department of Nuclear Medicine \\ University Hospital Dubrava, Zagreb \\ Croatia \\ ${ }^{4}$ Department of Endocrinology \\ University Hospital Dubrava, Zagreb \\ Croatia \\ 5 Department of Pharmacology \\ University Hospital Dubrava, Zagreb \\ Croatia
}

\begin{abstract}
The effect of supplementation with a fixed combination of antioxidants (beta-carotene, selenium, vitamins $\mathrm{C}$ and $\mathrm{E}$ ) on serum lipids was monitored in patients with newly detected Graves' disease. Measurements were made prior to the commencement of therapy and after 30 and 60 days. Patients were randomized into two groups. Test group comprised patients who received antioxidant supplementation in addition to methimazole, while patients treated with methimazole only were in the control group. The concentration of total and HDL-cholesterol increased significantly in test and control groups $(p<0.05)$ but these groups did not differ significantly. Concentration of LDL-cholesterol increased significantly in the test group only $(p<0.005)$ and was significantly different from the control group 60 days after the commencement of therapy $(p<0.005)$. Significant increase in the LDL-cholesterol concentration in the test group requires further investigations.
\end{abstract}

Keywords: Graves' disease, antioxidants, serum lipids, LDL-cholesterol

Graves' disease is an autoimmune disorder and the most common cause of hyperthyroidism. Graves' disease occurs more often in women with a female/male ratio of 5:1 and a population prevalence of 1 to $2 \%$. The disease is associated with circulating immunoglobulins that bind to and stimulate thyrotropin, the thyroid stimulating hormone (TSH) receptor, resulting in sustained thyroid overactivity (1). Through its hormones,

\footnotetext{
* Correspondence; e-mail: vesnav@kbd.hr
} 
thyroxine (T4) and triiodothyronine (T3), thyroid gland has a significant impact on the overall intensity of metabolism. Hyperthyreoidism causes decreasing serum lipid concentrations while hypothyreoidism causes an increase in serum lipid concentrations. Increases in metabolism intensity induced by hyperthyreoidism cause inappropriate energy expenditure, which results in lipid breakdown as a compensatory measure (2).

Increased concentrations of thyroid hormones T4 and T3 result in increased basal metabolic rate, increased oxygen consumption and in the production of large quantities of reactive oxygen species (3) which enhance oxidative stress (4). Supplementation with antioxidants can reduce oxidative stress in hyperthyroidism $(5,6)$ and has been shown to increase the rate of attaining euthyroid state when co-administered with medication in newly diagnosed Graves' disease (7).

There are only a few studies investigating the influence of antioxidant supplementation on lipid profile in general. The results of trials with antioxidants and their influence on lipid profile are equivocal. Results of Shargorodsky et al. (8) showed a significant increase in HDL-cholesterol and marginal declines in triglycerides as well as total cholesterol levels in antioxidant (vitamins C and E, co-enzyme Q10 and selenium) treated patients with multiple cardiovascular risk factors. The findings of Abdollahzad et al. (9) indicate that supplementation with vitamin $C$ over three months marginally decreases malondialdehyde (MDA) levels and improves lipid profiles in hemodialysis patients. On the other hand, the results of two animal studies indicate that vitamin E supplementation does not modulate the plasma lipid profile despite suppressing oxidative stress $(10,11)$. Differences in the type and dosage of antioxidant supplementation, as well as outcome measures, could explain this variability.

As there is no published study investigating the influence of antioxidant supplementation on the lipid profile in patients with newly diagnosed Graves' disease, it seemed reasonable to examine possible effects.

\section{EXPERIMENTAL}

\section{Subjects}

The study included 55 patients with newly detected Graves' disease, recruited from the Department of Nuclear Medicine and Department of Endocrinology, University Hospital Dubrava, Zagreb, Croatia. Informed consent was obtained from all subjects prior to study commencement. The study protocol was approved by the Ethics Committee of Dubrava University Hospital and was carried out in accordance with the ethics guidelines of the Helsinki Declaration.

To investigate the possible influence of antioxidant supplementation, half of the subjects included in this study received a fixed combination of antioxidants (beta-carotene, selenium, vitamins $C$ and $E$ ) in addition to methimazole. The patients were randomized into two groups. Test group comprised 27 patients, 23 women and 4 men, aged $44 \pm 12$ (mean \pm SD, range 18-66) and with the body mass index (BMI) $22.7 \pm 4.7 \mathrm{~kg} \mathrm{~m}^{-2}$ (mean \pm SD). Control group comprised 28 patients, 27 women and one man, aged $41 \pm 14$ (mean $\pm \mathrm{SD}$, range 18-65) and with BMI $23.2 \pm 3.6 \mathrm{~kg} \mathrm{~m}^{-2}$ (mean \pm SD). There were no significant age, sex or BMI differences between the groups. 
Test group received methimazole (Athyrazol, Jadran galenski laboratorij, Croatia) at a dose of $120 \mathrm{mg}$ daily (divided in three doses) in the first week, $80 \mathrm{mg}$ daily in the second week, $60 \mathrm{mg}$ daily in the third and fourth weeks, and $40 \mathrm{mg}$ daily (divided in two doses) for the next four weeks. An additional capsule daily of a fixed combination of antioxidants containing $6 \mathrm{mg} \beta$-carotene, $200 \mathrm{mg}$ vitamin C, $36 \mathrm{mg}$ vitamin E and $60 \mu \mathrm{g}$ Se (Symbion, Merck, Germany) was given with the main meal. Control group was administered methimazole alone, at the same dosage.

The patients were examined prior to the commencement of therapy (day 0), after 30 days and 60 days. The patients underwent clinical examination, thyroid gland ultrasonography, and blood sampling. Graves' disease was diagnosed on the basis of the clinical status, ultrasound finding, TSH suppression, and elevated concentrations of the $\mathrm{T}_{4}$ and $\mathrm{T}_{3}$ hormone free fractions $\left(\mathrm{FT}_{4}, \mathrm{FT}_{3}\right)$ as compared with reference values (12). Exclusion criteria were the presence of other chronic and acute diseases or conditions requiring use of other drugs or additional vitamins and minerals. Diabetic patients and pregnant women were excluded.

Questionnaires were completed with data of patient dietary habits, exercise, smoking, and previous state of health. None of the patients had previously suffered from any serious infection or other disease. None of the patients in either group reported any specific dietary habits, such as avoidance of some foods for religious or other reasons, and there were no vegetarians. Dietary intake and exercise were reported by patients during the study period. Although the differences were not noted they cannot be completely ruled out.

The patients were enrolled in the study and started treatment immediately after the diagnosis was established and were instructed how to take their therapy. The study was not placebo controlled and was unblinded although the main investigator did not know in which group the patients were randomised. Drug compliance was self-reported by study participants and was measured by determination of serum selenium concentrations (7).

\section{Laboratory analysis}

Fasting samples of venous blood were collected in the morning between 8.00 and 10.00 a.m. Blood was collected into a test tube without anticoagulant, and serum was separated for analysis of thyroid hormones $\mathrm{FT}_{4}, \mathrm{FT}_{3}$ and $\mathrm{TSH}$. Concentrations of $\mathrm{FT}_{4}$, $\mathrm{FT}_{3}$ and TSH were determined by the chemiluminescence method on a Vitros ECi analyzer using the test kit C1387000 for $\mathrm{FT}_{4}, \mathrm{C} 1315589$ for $\mathrm{FT}_{3}, \mathrm{C} 1912997$ for TSH (Ortho-Clinical Diagnostic, UK).

Plasma concentrations of total, HDL- and LDL-cholesterol and triglycerides were analysed on an Olympus AU2700 (Olympus Co., Japan).

\section{Statistical analysis}

The basic part of statistical data analysis consists of the usual descriptive statistics. The significance of changes in the parameters was tested in three measurements within each group: prior to the commencement of therapy (day 0) and on the 30th and 60th days of therapy, as well as between each measurement of both examined groups. The 
V. Bačić Vrca et al.: Antioxidant supplementation and serum lipids in patients with Graves' disease: Effect on LDL-cholesterol, Acta Pharm. 62 (2012) 115-122.

significance of the obtained results was determined by means of Wilcoxon's nonparametric test for dependent samples (within test group and control group) and Mann-Whitney's nonparametric test for independent samples (between the groups). Statistical analyses were performed using the MedCalc ver. 11.5 (Mariakerke, Belgium).

\section{RESULTS AND DISCUSSION}

\section{Triglycerides, total cholesterol, HDL- and LDL-cholesterol}

The starting concentration of triglycerides in serum, which was below the upper limit of the recommended value $\left(<1.7 \mathrm{mmol} \mathrm{L}^{-1}\right)(13)$, did not change significantly during the therapy in any group of patients and did not differ significantly between the groups in any measurement (Table I).

Total cholesterol concentration in serum, which was also lower than the upper limit of the recommended value $\left(<5 \mathrm{mmol} \mathrm{L}^{-1}\right)(13)$, significantly increased during the treatment in both groups of patients. In the test group, it increased from 4.11 to $5.02(p<0.01)$ after 30 days and to $5.86 \mathrm{mmol} \mathrm{L}^{-1}(p<0.005)$ after 60 days; in the control group, it rose from 3.90 to $5.29(p<0.01)$ and to $4.87 \mathrm{mmol} \mathrm{L}^{-1}(p<0.05)$, respectively. There was no statistically significant difference between test and control groups either after 30 or 60 days (Table I).

In the case of HDL-cholesterol, its starting serum concentration was also lower than the lowest recommended value $\left(>1 \mathrm{mmol} \mathrm{L}^{-1}\right)(13)$. In the test group, it significantly increased from 0.92 to $1.10(p<0.01)$ after 30 days and to $1.24 \mathrm{mmol} \mathrm{L}^{-1}(p<0.01)$ after 60 days from therapy commencent. Concentration of HDL-cholesterol in the control group increased from 0.99 to respective values of $1.11(p=0.075)$ and $1.46 \mathrm{mmol} \mathrm{L}^{-1}(p<0.005)$. No significant difference was recorded between the groups (Table I).

Before the commencement of therapy, LDL-cholesterol concentration in serum was below the upper limit of the recommended value $\left(<3 \mathrm{mmol} \mathrm{L}^{-1}\right)(13)$ in both groups of patients. In the test group, its concentration significantly increased from 2.32 to $3.32(p<$ $0.005) 30$ days after and to $3.76 \mathrm{mmol} \mathrm{L}^{-1}(p<0.005) 60$ days after the commencement of therapy, while there was no significant change in the control group. The groups significantly differed in respect to LDL-cholesterol concentration only 60 days after the commencement of therapy $(p<0.005)$ (Table I).

Although the measured serum concentrations of tryglicerides and total cholestrol in patients with additional antioxidant therapy showed a slight trend towards higher values compared to the control, the differences in lipid profile between the two groups of patients were not significant, with the exception of LDL-cholesterol, which was significantly higher in the test group than in the control group, the 60 days after supplementation and therapy. The results of Diekman et al. (14) indicate that changes in plasma LDL-cholesterol and HDL-cholesterol in hypo- and hyperthyroid patients are related to changes in FT4. Significantly higher serum concentrations of LDL-cholesterol in the group of patients treated additionally with antioxidants (test group) could be related to faster normalization of thyroid hormones compared to the control group. 


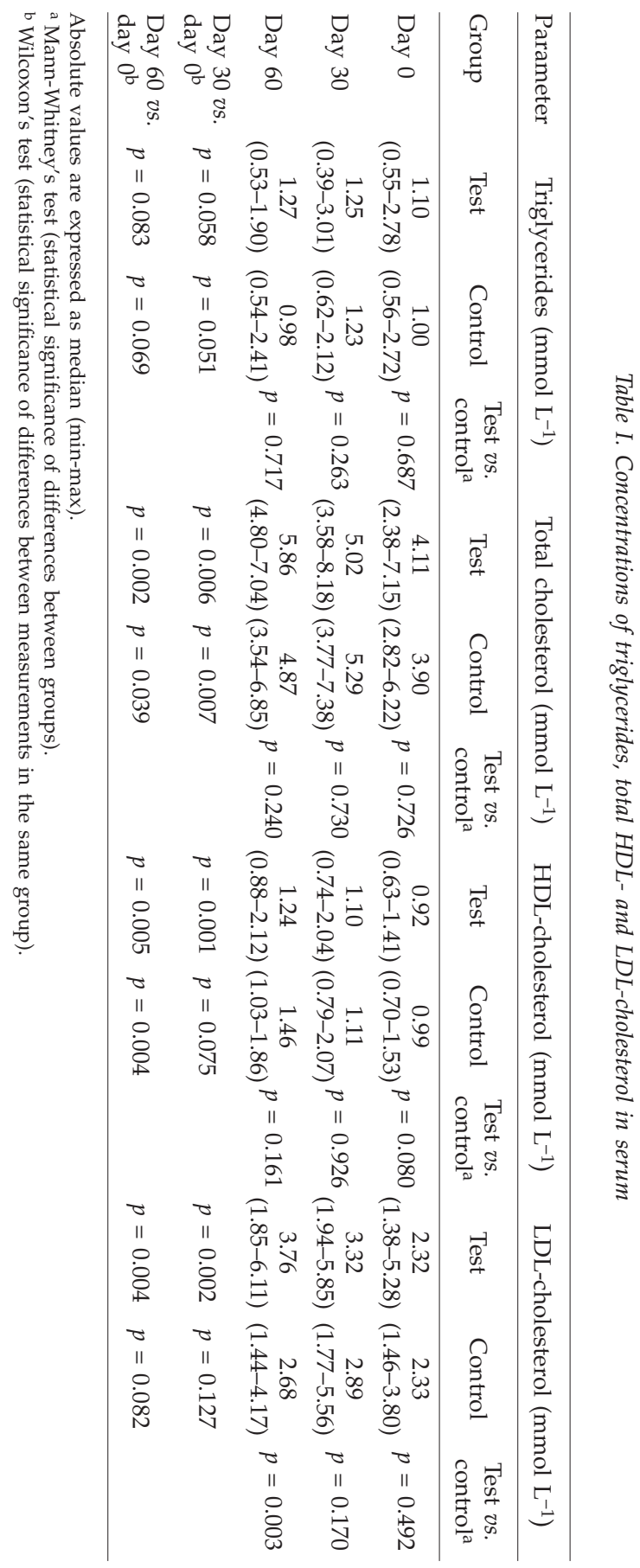


V. Bačić Vrca et al.: Antioxidant supplementation and serum lipids in patients with Graves' disease: Effect on LDL-cholesterol, Acta Pharm. 62 (2012) 115-122.

\section{Thyroid hormones and TSH}

The serum $\mathrm{FT}_{4}$ concentration, which was above the upper limit of the reference interval (10.00-28.20 pmol L $\left.{ }^{-1}\right)$ (12) prior to the commencement of treatment, gradually decreased in both groups during the therapy. In both groups, a significant decrease $(p<$ 0.001) of $\mathrm{FT}_{4}$ concentration was observed. A significant difference in $\mathrm{FT}_{4}$ was observed between the groups after $30(p<0.001)$ and 60 days of treatment $(p<0.005$ and resp.) (Table II), with the test group showing lower $\mathrm{FT}_{4}$ level than the control group.

It is also noteworthy that the serum concentration of $\mathrm{FT}_{3}$ hormone (reference values $\left.4.26-8.10 \mathrm{pmol} \mathrm{L}^{-1}\right)(12)$ significantly decreased $(p<0.001)$ in both examined groups during treatment. A statistically significant difference between the groups (Table II) was determined after 30 days of treatment $(p<0.001)$ but not after 60 days.

During the study, a statistically significant increase in TSH activity (reference values $\left.0.47-4.68 \mathrm{mU} \mathrm{L}^{-1}\right)(12)$ was determined in the test group $(p<0.001)$ but not in the control group. Furthermore, the study clearly demonstrated a statistically significant difference in this hormone activity between the groups $(p<0.05)$ after 60 days (Table II).

The significant difference between the test and control groups in respect to the rate of attaining euthyroidism indicates the favourable effect of additional therapy with a fixed combination of antioxidants. Antioxidants may affect the peripheral conversion of thyroid hormones by deiodination and/or mechanism of cell membrane defence, the integrity of which can affect the activity of deiodinases (15). Among the antioxidants, as supplementary therapy in Graves' disease, selenium has probably a central role in the circumstances of moderate selenium deficiency because of its action, through selenium dependent deiodinase, on transformation of the thyroid hormones and thus indirectly on the LDL-cholesterol concentration (7). More experiments are needed to see which aspects of this combination of antioxidants are most beneficial.

Table II. Concentrations of $\mathrm{FT}_{4}, \mathrm{FT}_{3}$ and $\mathrm{TSH}$ in serum ${ }^{a}$

\begin{tabular}{lcccccc}
\hline Parameter & \multicolumn{2}{c}{$\mathrm{FT}_{4}\left(\mathrm{pmol} \mathrm{L}^{-1}\right)$} & \multicolumn{2}{c}{$\mathrm{FT}_{3}\left(\mathrm{pmol} \mathrm{L}^{-1}\right)$} & \multicolumn{2}{c}{$\mathrm{TSH}\left(\mathrm{mU} \mathrm{L}^{-1}\right)$} \\
\hline Group & Test & Control & Test & Control & Test & Control \\
\hline \multirow{2}{*}{ Day 0 } & 48.2 & 46.8 & 22.0 & 24.8 & 0.00 & 0.00 \\
& $(28.5-90.0)$ & $(31.4-82.3)$ & $(9.6-47.8)$ & $(11.3-37.0)$ & $(0.00-0.04)$ & $(0.00-0.00)$ \\
\multirow{2}{*}{ Day 30 } & 17.2 & 25.3 & 8.1 & 11.5 & 0,00 & 0.00 \\
& $(8.4-27.4)^{\mathrm{b}, \mathrm{e}}$ & $(8.6-41.7)^{\mathrm{e}}$ & $(4.7-14.9)^{\mathrm{c}, \mathrm{e}}$ & $(4.0-20.7)^{\mathrm{e}}$ & $(0.00-0.45)$ & $(0.00-1.56)$ \\
Day 60 & 9.8 & 13.6 & 6.5 & 6.4 & 0.00 & 0.00 \\
& $(5.6-18.3)^{\mathrm{c}, \mathrm{e}}$ & $(6.0-40.8)^{\mathrm{e}}$ & $(3.6-13.5)^{\mathrm{e}}$ & $(4.0-12.3)^{\mathrm{e}}$ & $(0.00-4.10)^{\mathrm{d}, \mathrm{e}}$ & $(0.00-1.20)$ \\
\hline
\end{tabular}

Absolute values are expressed as median (min-max).

a For more information see reference 7. Significant difference between test and control group: ${ }^{\mathrm{b}} p<0.001 ;{ }^{\mathrm{c}} p<$ $0.01 ;{ }^{d} p<0.05$ (Mann-Whitney's test); e Statistically significant difference $v$ s. day 0 in the same group (Wilcoxon's test). 


\section{CONCLUSIONS}

The results of the study indicate that supplementation with a combination of antioxidants does not significantly influence serum concentrations of total and HDL-cholesterol as well as triglycerides 60 days after the commencement of therapy in patients with newly diagnosed Graves' disease, except for the concentration of LDL-cholesterol ( $p$ $<0.005)$. Application of antioxidants probably accelerated normalization of the thyroid hormone concentrations in patients with Graves' disease. Significant increase of LDL-cholesterol concentration in the group of patients with the antioxidant treatment after 60 days could be related to the significant decrease of $\mathrm{FT}_{4}$ and $\mathrm{FT}_{3}$ serum concentrations compared to the control group. Further targeted investigations are needed in order to clarify the nature of this specific change.

\section{REFERENCES}

1. G. J. Kahaly, S. K. Grebe, M. A. Lupo, N. McDonald and J. A. Sipos, Graves' disease; diagnostic and therapeutic challenges (multimedia activity), Am. J. Med. 124 (2011) 2-3; DOI: 10.1016/j. amjmed. 2011.03.001.

2. L. H. Duntas, Thyroid disease and lipids, Thyroid 12 (2002) 287-293; DOI: 10.1089/ 10507250252949405287.

3. U. Subudhi and G. B. Chainy, Expression of hepatic antioxidant genes in 1-thyroxine-induced hyperthyroid rats: regulation by vitamin E and curcumin, Chem. Biol. Interact. 183 (2010) 304-316; DOI: 10.1016/j.cbi.2009.11.004.

4. Lj. Mayer, Z. Romic, F. Skreb, V. Bacic Vrca, I. Cepelak, T. Zanic-Grubisic and M. Kirin, Antioxidants in patients with hyperthyroidism, Clin. Chem. Lab. Med. 42 (2004) 154-158; DOI: 10.1515/ CCLM.2004.028.

5. A. Seven, O. Seymen, S. Hatemi, H. Hatemi, G. Yiğit and G. Candan, Antioxidant status in experimental hyperthyroidism: effect of vitamin E supplementation, Clin. Chim. Acta 256 (1996) 65-74; DOI: 10.1016/S0009-8981(96)06415-7.

6. A. Seven, E. Taşan, F. Inci, H. Hatemi and G. Burçak, Biochemical evaluation of oxidative stress in propylthiouracil treated hyperthyroid patients. Effects of vitamin C supplementation, Clin. Chem. Lab. Med. 6 (1998) 767-770; DOI: 10.1515/CCLM.1998.136.

7. V. B. Vrca, F. Skreb, I. Cepelak, Z. Romic and Lj. Mayer, Supplementation with antioxidants in the treatment of Graves' disease; the effect on glutathione peroxidase activity and concentration of selenium, Clin. Chim. Acta 341 (2004) 55-63; DOI: 10.1016/j.cccn.2003.10.028.

8. M. Shargorodsky, O. Debby, Z. Matas and R. Zimlichman, Effect of long-term treatment with antioxidants (vitamin C, vitamin E, coenzyme Q10 and selenium) on arterial compliance, humoral factors and inflammatory markers in patients with multiple cardiovascular risk factors, Nutr. Metab. 7 (2010) 55; DOI: 10.1186/1743-7075-7-55.

9. H. Abdollahzad, S. Eghtesadi, I. Nourmohammadi, M. Khadem-Ansari, H. Nejad-Gashti and A. Esmaillzadeh, Effect of vitamin C supplementation on oxidative stress and lipid profiles in hemodialysis patients, Int. J. Vitam. Nutr. Res. 79 (2009) 281-287; DOI: 10.1024/0300-9831.79.56.281.

10. F. Deyhim, C. Gonzales, C. Garcia, A. Villarreal, K. Garcia, R. Rios, K. Mandadti and B. S. Patil, Vitamin E does not modulate plasma lipid profile or C-reactive protein despite suppressing oxidative stress in orchiectomized rats, J. Med. Food 10 (2007) 559-562; DOI: 10.1089/jmf.2006.245. 
11. E. A. Lucas, T. Y. Chen, S. C. Chai, L. Devareddy, S. Juma, C. I. Wei, Y. B. Tripathi, B. P. Daggy, D. F. Hwang and B. H. Arjmandi, Effect of vitamin E on lipid parameters in ovariectomized rats, J. Med. Food 9 (2006) 77-83; DOI: 10.1089/jmf.2006.9.77.

12. L. Thomas, Thyroid Function, in Clinical Laboratory Diagnostics, $1^{\text {st }}$ ed., TH-Books Verlagsgesellschaft mbH, Frankfurt/Main 1998, pp. 1004-1023.

13. G. De Backer, E. Ambrosioni, K. Borch-Johnsen, C. Brotons, R. Cifkova, J. Dallongeville, S. Ebrahim, O. Faergeman, I. Graham, G. Mancia, V. M. Cats, K. Orth-Gomér, J. Perk, K. Pyörälä, J. L. Rodicio, S. Sans, V. Sansoy, U. Sechtem, S. Silber, T. Thomsen and D. Wood, European guidelines on cardiovascular disease and prevention in clinical practice, Atherosclerosis 171 (2003) 145-55; DOI: 10.1016/j.atherosclerosis.2003.10.001.

14. M. J. Diekman, N. Anghelescu, E. Endert, O. Bakker and W. M. Wiersinga, Changes in plasma low-density lipoprotein (LDL)- and high-density lipoprotein cholesterol in hypo- and hyperthyroid patients are related to changes in free thyroxine, not to polymorphisms in LDL receptor or cholesterol ester transfer protein genes, J. Clin. Endocrinol Metab. 85 (2000) 1857-1862; DOI: 10.1210/jc.85.5.1857.

15. E. Brzezinska-Slebodinzska, Fever induced oxidative stress: the effect on thyroid status at the 5'-monodeionidase activity, protective role of selenium and vitamin E, J. Physiol. Pharmacol. 52 (2001) 275-284.

\section{$S A \check{Z} E T A K$}

\section{Suplementacija antioksidansima i serumski lipidi kod bolesnika s Gravesovom bolešću: Učinak na LDL-kolesterol}

VESNA BAČIĆ VRCA, LJILJANA MAYER, FRANJO SKREB, DARIO RAHELIĆ i SREĆKO MARUŠIĆ

Promatran je učinak suplementacije fiksnom kombinacijom antioksidansa (beta-karoten, selen, vitamini C i E) na koncentracije serumskih lipida, u odnosu na brzinu postizanja eutiroze, u bolesnika s novo otkrivenom Gravesovom bolešću. Bolesnici su randomizirani u dvije skupine. Test skupinu sačinjavali su bolesnici koji su liječeni metimazolom (tiamazolom), te su dodatno dobivali antioksidanse, a kontrolnu skupinu bolesnici koji su uzimali samo metimazol (tiamazol). Koncentracije ukupnog i HDL-kolesterola u serumu porasle su tijekom terapije kod bolesnika iz obje skupine $(p<0.05)$, no nisu se međusobno značajno razlikovale 60 dana nakon početka terapije. Kod bolesnika test skupine, koncentracija LDL-kolesterola značajno se povećala $(p<0.005)$ i bila je značajno različita od one u kontrolnoj skupini $(p<0.005) 60$ dana nakon početka liječenja. Zbog značajnog porasta koncentracije LDL-kolesterola kod bolesnika s Gravesovom bolešću koji su dodatno uzimali antioksidanse potrebna su daljnja istraživanja u cilju pojašnjenja opisanih promjena.

Ključne riječi: Gravesova bolest, antioksidansi, serumski lipidi, LDL-kolesterol

Farmaceutsko-biokemijski fakultet Sveučilišta u Zagrebu, Zagreb

Klinička bolnica Dubrava, Zagreb

Klinički bolnički centar »Sestre milosrdnice«, Zagreb 